\title{
CHIEF EDITOR'S NOTE ON THE NEW RUSSIAN LAW ON GROUP LITIGATION
}

\author{
DMITRY MALESHIN,
}

Lomonosov Moscow State University (Moscow, Russia)

https://doi.org/10.21684/2412-2343-2019-6-4-4-5

Recommended citation: Dmitry Maleshin, Chief Editor's Note on the New Russian Law on Group Litigation, 6(4) BRICS Law Journal 4-5 (2019).

Three Russian procedural codes - the Civil Procedural Code of 2002, the Arbitrazh (Commercial) Procedural Code of 2002 and the Code of Administrative Litigation of 2015 - were amended in 2019 by the provisions concerning group litigation. These amendments may be treated as one of the most important steps in the recent reform of Russian civil procedure.

Historically, class actions were not admitted in Russia, as was also the case in many other continental European countries. The main argument underpinning this position was the existence of joinder of parties which allows effectively protecting the violated rights of a group of people. Then in the middle of the 1990s scholars began to discuss the introduction of class actions in Russia. In that period, a special drafting committee started to prepare the new Civil Procedural Code, which finally came into force in 2003 . Class actions were not included in the code at that time. It took sixteen years to convince the Russian legislator to introduce class actions.

The 2019 amendments introduced the "pure" model of class actions that exists in many Anglo-Saxon countries. If we compare Russia with other continental European countries such as Germany or France, we find that in Russia there are no restrictions on the use of class actions, there are no limitations imposed by any specific field of law, as is the case in Germany, for example. Therefore, it may be said that the Russian model of class actions is the most radical among other continental European countries.

Special chapter 22.3 "Considering Cases Concerning Group Litigation" was amended in the Civil Procedural Code, which came into force on 1 October 2019. The same chapter was amended in the Arbitrazh (Commercial) Code and the Code 
of Administrative Procedure. According to Article 244.20, the certification of the group has the following features: (1) one defendant for all the members of the group; (2) all the members have commonality of interests and rights; (3) there are common facts in the basis of the action; and (4) all the members use the same type of dispute resolution. The representative of the group can be either a citizen or an organization. And the opt-in model has been introduced. This means that all the members should accept the invitation to join the group before the beginning of the stage of arguments during the judicial hearings. Furthermore, the case should be considered in eight months; preliminary hearings are obligatory in this kind of cases, where a judge considers the certification of the group; the representative of the group concludes an agreement with all the members of the group; and the agreement should be concluded in a notary form.

In spite of the fact that many Russian legal scholars were disappointed with the idea of introducing class actions, I am sure that group litigation will be successful in Russia. For there are also cultural reasons for the effective use of class actions. One of the particularities of Russian civil procedure is the active role of the state authorities, which has different procedural forms - the activities of the judge and the specific procedural participation of the procurator are examples of this state overwatch. This may be seen as the paternalistic character of Russian civil procedure, where the state authorities are on duty to guard the rights of less-protected groups of citizens. The reason for this is cultural collectivism, which is still widespread in Russian society. One of the advantages of group litigation is also the protection of citizens who do not have the resources to protect themselves. Again, that is why group litigation may be treated as an example of a paternalistic type of civil procedure.

There are really no reasons why the future of group litigation in Russia should not be successful. 